\title{
Pengaruh Citra Perusahaan dan Kebijakan Promosi Terhadap Kepuasan Pelanggan pada Produk Sepeda Motor Honda Merek Scoopy di Kota Banda Aceh
}

\author{
RADHIANA \\ Fakultas Ekonomi, Universitas Serambi Mekkah, \\ Jalan Batoh, Lueng Bata, Kota Banda Aceh, Provinsi Aceh, Indonesia \\ radhiana@serambimekkah.ac.id \\ MUKHDASIR * \\ Fakultas Ekonomi, Universitas Serambi Mekkah, \\ Jalan Batoh, Lueng Bata, Kota Banda Aceh, Provinsi Aceh, Indonesia \\ mukhdasir4@gmail.com
}

\section{Article's history:}

Received 16 July 2021; Received in revised form 12 December 2021; Accepted 15 December, 2021; Published 30 December 2021. All rights reserved to the Lembaga Otonom Lembaga Informasi dan Riset Indonesia (KITA INFO dan RISET).

\section{Suggested citation:}

Radhiana, R., Mukhdasir, M. 2021. Pengaruh Citra Perusahaan dan Kebijakan Promosi Terhadap Kepuasan Pelanggan pada Produk Sepeda Motor Honda Merek Scoopy di Kota Banda Aceh. JEMSI (Jurnal Ekonomi, Manajemen, dan Akuntansi), Volume 7 (2): 74-82. DOI: https://doi.org/10.35870/jemsi.v7i2.607.

\section{ABSTRAK:}

Penelitian ini merupakan studi empiris mengenai pengaruh citra perusahaan dan kebijakan promosi terhadap kepuasan pelanggan pada produk sepeda motor Honda Scoopy. Tujuan penelitian adalah untuk mengetahui pengaruh citra perusahaan dan kebijakan promosi baik secara parsial maupun simultan terhadap kepuasan pelanggan pada produk sepeda motor Honda Scoopy. Penelitian ini menggunakan metode sensus dengan menggunakan seluruh populasi pelanggan sebagai sampel penelitian. Sampel dalam penelitian ini adalah pelanggan yang menggunakan produk sepeda motor Honda Scoopy yang berjumlah sebanyak 113 responden. Penelitian ini menggunakan model analisis regresi linier berganda. Hasil penelitian menjelaskan bahwa citra perusahaan berpengaruh signifikan terhadap kepuasan pelanggan pada produk sepeda motor Honda Scoopy dengan nilai t-hitung $(3,404)>$ t-tabel $(1,984)$. Kemudian kebijakan promosi juga berpengaruh signifikan terhadap kepuasan pelanggan pada produk sepeda motor Honda Scoopy dengan nilai t-hitung $(3,843)>$ t-tabel $(1,984)$. Citra perusahaan dan kebijakan promosi secara bersama-sama berpengaruh signifikan terhadap kepuasan pelanggan pada produk sepeda motor Honda Scoopy dengan nilai F-hitung $(19,857)>$ F-tabel $(3,087)$. Hubungan korelasi antara citra perusahaan dan kebijakan promosi dengan kepuasan pelanggan pelanggan pada produk sepeda motor Honda Scoopy adalah positif dan tergolong kuat dengan nilai $\mathrm{R}$ sebesar 0,515 (51,5\%). Peran kedua variabel tersebut dalam mempengaruhi kepuasan pelanggan pada produk sepeda motor honda scoopy juga lebih dominan dibanding faktor lainnya di luar dari model ini dengan nilai R2 sebesar 0,265 .

Kata Kunci: Citra Perusahaan; Kebijakan Promosi; Kepuasan Pelanggan.

JEL Classification: M51; J29. 


\section{PENDAHULUAN}

Motor matik masih jadi primadona di pasar domestik beberapa Tahun belakangan ini. Hal ini mengacu laman resmi Asosiasi Sepeda Motor Indonesia (AISI) kontribusi penjualannya mencapai 86,95 persen sampai pertengahan 2021 ini. Tipe motor matik dipilih lantaran kepraktisannya, pengendara cukup atur gas, mengontrol tuas rem, dan kendaraan bisa dengan mudah melaju. Perubahan teknologi komunikasi, berkembangnya pendidikan dan penghasilan masyarakat menambah kesadaran konsumen untuk mendapatkan kepuasan yang lebih baik menjadi semakin tinggi. Ketertarikan masyarakat Indonesia terutama di Kota Banda Aceh terhadap skutik terus meningkat. Sepeda motor bertransmisi otomatis itu menjadi pilihan banyak orang sebagai kendaraan harian. Dengan bentuk yang unik, ternyata Honda Scoopy memiliki kekurangan dalam kinerja. Kapasitas mesinnya berada di bawah lawannya, yakni Yamaha Fino, sehingga perusahaan harus selalu memperhatikan kebutuhan dan keinginan konsumen agar para pelanggan tetap puas memakai produk sepeda motor Honda merek scoopy

Perusahaan menyadari bahwa kepuasan pelanggan adalah hal yang utama yang harus dicapai perusahaan. Kepuasan pelanggan tidak saja hanya ditentukan oleh kewajaran harga, tetapi juga ditentukan oleh citra perusahaan. Sutanto (2009) menemukan bahwa untuk mencapai kepuasan pelanggan maka pengelola industri otomotif harus memperhatikan citra perusahaan. Demikian halnya dengan kebijakan promosi dimana promosi merupakan proses komunikasi suatu perusahaan dengan pihak-pihak yang berkepentingan sekarang, dan yang akan datang serta masyarakat (Kotler, 2005). Pemasaran modern memerlukan lebih dari sekedar mengembangkan produk yang baik, menetapkan harga yang menarik dan membuatnya dapat terjangkau. Perusahaan-perusahaan juga harus berkomunikasi dengan pihak-pihak yang berkepentingan sekarang dan yang akan datang, dan masyarakat umum.

\section{TINJAUAN KEPUSTAKAAN}

\section{Kepuasan Pelanggan}

Kepuasan maupun ketidakpuasan konsumen menjadi topik yang hangat dibicarakan dalam berbagai lapisan masyarakat juga perusahaan industri dan jasa karena kepuasan konsumen ditentukan oleh kualitas barang dan jasa. Pada dasarnya pengertian kepuasan/ketidakpuasan merupakan selisih antara harapan dan kinerja yang dirasakan. Menurut Zeithaml dan Mary Jo (1996) yang mengatakan bahwa kepuasan pelanggan dipengaruhi oleh kualitas layanan, kualitas produk, harga, faktor situasi dan faktor manusia. Sedangkan Kotler, dkk (2000) mengatakan bahwa kepuasan adalah tingkat perasaan seseorang setelah membandingkan kinerja produk (atau hasil) yang ia rasakan dengan harapannya. Jadi, tingkat kepuasan merupakan fungsi dari perbedaan antara kinerja yang dirasakan (perceived performance) dan harapan (expectations).

Menurut Supranto (2002), pengertian kepuasan konsumen adalah kinerja suatu barang sekurangkurangnya sama dengan apa yang diharapkan oleh konsumen, dimana pada hakikatnya pengukuran kepuasan menyangkut penentuan tiga faktor yaitu: 1). Pilihan tentang ukuran kinerja yang tepat, 2). Proses pengukuran secara normatif, dan Instrumen dan 3). Tehnik pengukuran yang di gunakan untuk menciptakan suatu indikator. Pada hakikatnya setiap perusahaan yang bergerak dalam perusahaan jasa (pelayanan) mengenal tiga unsur keunggulan daya saing (Supranto (2002), yaitu :

a. Keunggulan sumber: meliputi ketrampilan dan sumber daya serta dana.

b. Keunggulan posisional; menyangkut nilai bagi pelangganan dan biaya yang lebih rendah.

c. Keunggulan kinerja ; meliputi kepuasan dan kesetiaan pelanggan, pangsa pasar dan kemampuan berlaba (profitabilitas).

Ketiga hal tersebut di atas dapat menjadi prioritas khususnya bagi perusahaan yang bergerak dalam bidang pemasaran jasa baik itu perusahaan penerbangan, rumah sakit maupun bidang produk makanan siap saji sehingga masing-masing perusahaan mampu bersaing secara sehat dan mampu merebut pangsa pasar lebih luas. Engel (2002) dalam bukunya Custumer Behavior, mendefinisikan: kepuasan adalah sebagai evaluasi purnabeli, bahwa suatu alternatif yang dipilih tersebut setidaknya memenuhi atau melebihi harapan, jadi alternatif tersebut setidaknya bekerja memenuhi atau melebihi harapan, sedangkan ketidakpuasan adalah hasil dari harapan yang diteguhkan secara negatif. 


\section{Citra Perusahaan}

Setiap perusahaan, secara sadar maupun tidak, pasti mempunyai sebuah citra di masyarakat. Citra itu dapat berperingkat baik, sedang, maupun buruk. Dampak peringkat citra yang berbeda antar perusahaan dalam suatu industri ikut mempengaruhi keberhasilan mereka dalam kegiatan bisnis dan pemasaran produknya. Hal ini dikarenakan persepsi konsumen terhadap citra perusahaan dapat memberi pengaruh pada kecenderungan perilaku konsumen. Citra perusahaan tidak bisa direkayasa, untuk itu, perusahaan perlu mengkomunikasikan secara jelas tentang perusahaan yang diharapkan, sehingga dapat mengarahkan masyarakat dalam mencitrakan perusahaan secara positif. Untuk lebih jelasnya penulis menyampaikan pendapat dari beberapa para ahli berikut: Definisi citra perusahaan (corporate image) atau organizational image menurut beberapa ahli pemasaran, seperti Kotler dan Keller (2009), yaitu "Such as perceptions about the people who make up the organization and who provide the service..that may affect evaluation of service quality directly or indirectly. One particularly important association is company credibility and perceived expertice, trustworthiness and likeability".

Sedangkan menurut Sutojo (2004) mengatakan bahwa citra perusahaan adalah sebagai berikut: "Persepsi masyarakat terhadap jati diri perusahaan. Dari definisi-definisi di atas dapat disimpulkan bahwa pada intinya citra perusahaan merupakan hasil persepsi mengenai sekumpulan orang yang membentuk suatu organisasi dan yang menyediakan pelayanan, dimana persepsi ini dapat mempengaruhi evaluasi mengenai kualitas pelayanan baik secara langsung maupun tidak langsung. Citra perusahaan memiliki asosiasi erat dengan kepercayaan konsumen akan kemampuan perusahaan (credibility), pengakuan konsumen atas keahlian perusahaan (perceived expertise), kepercayaan konsumen akan nilai-nilai perusahaan (trustworthiness), dan kemampuan perusahaan untuk menyenangkan pelanggannya (likeability). Maka sudah seharusnya perusahaan terus menjaga dan meningkatkan citra mereka mengingat keuntungan-keuntungan dari sebuah corporate image yang positif. Setiap perusahaan pasti mempunyai citra di mata publiknya, citra tersebut dapat dipersepsikan berbeda oleh setiap orang tergantung pada persepsi yang dilihat mereka mengenai apa yang mereka rasakan terhadap citra perusahaan tersebut. Citra itu dapat berdampak positif dan negatif. Menurut Zhang (2009) Dimensi atau sub variabel citra perusahaan yaitu:

1. Disukai (Likeability) adalah Kemampuan untuk disukai menunjukkan daya tarik sumber pesan di mata audience atau khalayak. Diantaranya yaitu (keramahan karyawan, perhatian karyawan secara personal).

2. Kompetensi (Competence) adalah pengintegrasian dari pengetahuan, keterampilan, dan sikap yang memungkinkan untuk melaksanakan satu cara efektif. Diantaranya yaitu (pengetahuan karyawan, keakuratan dalam pencatatan sebuah dokumen).

3. Kualitas (Quality) adalah segala sesuatu yang mampu memenuhi keinginan atau kebutuhan pelanggan. Diantaranya yaitu (peralatan sarana penunjang, penampilan karyawan, kemudahan untuk berkomunikasi, dapat dipercaya, kecepatan penyelesaian klaim, kesediaan karyawan membantu masalah pemegang polis, kepastian dan rasa aman pemegang polis, karyawan yang terpercaya).

4. Kinerja (Performance) adalah hasil atau tingkat keberhasilan seseorang secara keseluruhan selama periode tertentu di dalam melaksanakan tugas dibandingkan dengan berbagai kemungkinan, seperti standar hasil kerja, target atau sasaran atau kriteria yang telah ditentukan terlebih dahulu dan telah disepakati bersama. Diantaranya yaitu (kinerja usaha perusahaan, keakuratan hasil kerja karyawan).

5. Tanggung Jawab (Responsibility) adalah sikap moral untuk melaksanakan kewajibannya, yaitu kewajiban perusahaan dalam membayar klaim.

\section{Kebijakan Promosi}

Promosi menurut Alma (2007) adalah sejenis komunikasi yang memberi penjelasan yang menyangkutkan calon konsumen tentang barang/jasa. Pada hakekatnya promosi adalah suatu bentuk komunikasi pemasaran,yang di maksud komunikasi pemasaran adalah aktifitas pemasaran yang berusaha menyebarkan informasi, mempengaruhi dan mengingatkan pasar sasaran atas perusahaan dan produk nya agar bersedia menerima, membeli dan layak pada produk atau jasa yang di tawarkan perusahaan yang berdasangkutan (Swastha dan Irawan, 2001). Menurut Saladin (2003) promosi adalah suatu komunikasi, informasi penjual dan pembeli yang berjualan untuk merubah sikap dan tingkah laku pembeli yang tadinya tidak mengenal menjadi mengenal sehingga pembeli dan tetap mengingat produk tersebut. Menurut Kasmir (2004) proses evaluasi persepsi konsumen terhadap kebijakan promosi adalah:

1. Melalui iklan, promosi penjualan dan publikasi.

2. Melalui senyum dan suasana ramah. 
3. Segmentasi dan Inovasi.

4. Positioning.

5. Analisis, perencanaan, implementasi dan pengendalian sebagai sarana pemasaran. berikut:

Promosi dalam praktek menurut Swastha (2006) dapat dilakukan dengan mendasarkan pada tujuan-tujuan

a. Memodifikasi tingkah laku.

b. Memberitahu.

c. Membujuk.

d. Mengingatkan.

\section{Kerangka Konseptual}

Untuk mendapatkan pengertian dan gambaran yang lebih jelas tentang pengaruh citra perusahaan dan kebijakan promosi terhadap kepuasan pelanggan dapat digambarkan kerangka konseptual sebagai berikut:

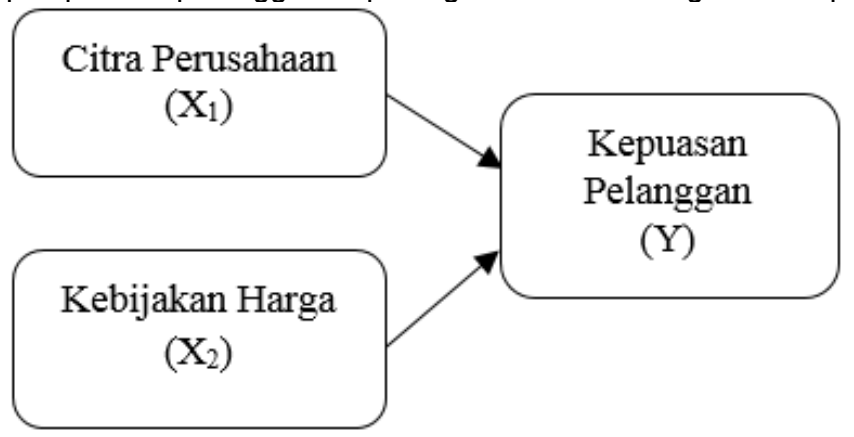

Gambar 1. Kerangka Pemikiran

\section{Hipotesis Penelitian}

Berdasarkan rumusan masalah, maka hipotesis dalam penelitian ini adalah:

1. Citra perusahaan dan kebijakan promosi berpengaruh signifikan terhadap kepuasan pelanggan pelanggan pada Produk sepeda motor Honda Scoopy

2. Citra perusahaan dan kebijakan promosi berpengaruh signifikan terhadap kepuasan pelanggan pada produk sepeda motor Honda Scoopy

3. Citra perusahaan dan kebijakan promosi berpengaruh signifikan terhadap kepuasan pelanggan pada Produk sepeda motor Honda Scoopy.

\section{METODE PENELITIAN}

\section{Lokasi dan Objek Penelitian}

Adapun yang menjadi lokasi atau tempat penelitian ini adalah pelanggan di Kota Banda Aceh. Objek pada penelitian ini adalah pelanggan pada produk sepeda motor Honda Scoopy yang dikaitkan dengan citra perusahaan dan kebijakan promosi terhadap kepuasan pelanggan.

\section{Populasi dan Sampel}

Populasi (population) mengacu pada keseluruhan kelompok orang, kejadian, atau hal minat yang ingin di investigasikan (Sekaran, 2005). Sedangkan sampel (sample) adalah sebagian dari populasi. Sampel terdiri dari sejumlah anggota yang dipilih dari populasi (Sekaran, 2005). Populasi dalam penelitian ini adalah seluruh Pelanggan Produk sepeda motor Honda Scoopy yang jumlahnya tak terhingga di Kota Banda Aceh, sehingga tehnik penarikan sampel dalam penelitian ini digunakan tehnik non probality Sampling yaitu setiap anggota populasi tidak diberikan peluang sama untuk dijadikan sebagai sampel dalam penelitian. Menurut Sugiyono (2005) dalam teknik penarikan sampel secara non probality Sampling dapat dilakukan dengan cara Accidentlal Sampling adalah tehnik penentuan sampel berdasarkan kebetulan, yaitu siapa saja yang secara kebetulan bertemu dengan peneliti dapat dijadikan sebagai sampel, bila dipandang orang yang kebetulan ditemui itu cocok sebagai sumber data. 
Berdasarkan pengamatan penelitian dari jumlah populasi sebanyak 212 orang, hanya 113 orang pelanggan yang masih menggunakan sepeda motor honda merek scoopy berdasarakan hasil pengamatan di beberapa kecamatan di Kota Banda

\section{Teknik Pengumpulan Data}

Pengumpulan data dalam penelitian ini dilakukan dengan beberapa cara:

1) Tinjauan kepustakaan

Teknik pengumpulan data dengan cara mempelajari buku, jurnal, dan penelitian-penelitian terdahulu yang berhubungan dengan masalah yang ada dalam penelitian ini.

2) Pengumpulan data langsung di lapangan.

Teknik pengumpulan data langsung di lapangan dilakukan dengan cara;

a. Observasi

b. Wawancara kepada pihak-pihak terkait.

c. Memberikan kuesioner kepada pihak yang bersangkutan.

\section{Teknik Analisis Data}

Teknik analisis data yang digunakan dalam penelitian ini adalah sebagai berikut :

1) Analisis deskriptif adalah suatu analisis yang menggambarkan tanggapan responden mengenai pengaruh citra perusahaan dan kebijakan promosi terhadap kepuasan pelanggan yang diperoleh dari hasil jawaban responden.

2) Model analisis yang digunakan dalam penelitian ini adalah model regresi linier berganda. Menurut Priyatno (2012) analisis regresi linier berganda adalah alat analisis yang dapat digunakan untuk mengetahui pengaruh antara variabel bebas dan variabel terikat yaitu antara citra perusahaan $\left(X_{1}\right)$, kebijakan promosi $\left(X_{2}\right)$, dan kepuasan pelanggan $(Y)$. Mencari persamaan garis regresi dengan menggunakan rumus:

Keterangan :

$$
Y=a+\beta_{1} x_{1}+\beta_{2} x_{2}+e
$$

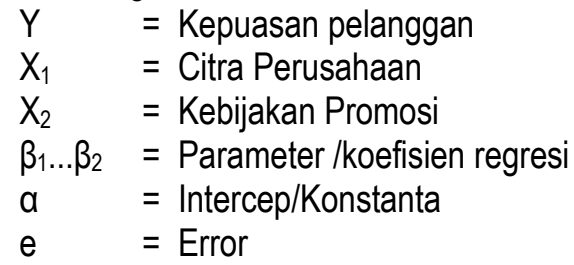

\section{Skala Pengukuran}

Data deskriptif yang akan dianalisis di konversi menjadi data yang berbentuk angka-angka (kualitatif). Langkah yang dilakukan dengan merubah data pertanyaan kuesioner ke dalam skala likert. Kategori pertanyaan yang dirancang dalam kuesioner diberi skor 1-5 dengan kategori menurut Sekaran (2005) adalah dapat dilihat pada Tabel 1. Skala Likert menggunakan lima tingkatan yaitu, sebagai berikut:

Tabel 1. Skala Pengukuran

\begin{tabular}{|c|l|c|}
\hline No & \multicolumn{1}{|c|}{ Pernyataan } & Skor \\
\hline 1 & Sangat Setuju (SS) & 5 \\
\hline 2 & Setuju (S) & 4 \\
\hline 3 & Kurang Setuju (KS) & 3 \\
\hline 4 & Tidak Setuju (TS) & 2 \\
\hline 5 & Sangat Tidak Setuju (STS) & 1 \\
\hline
\end{tabular}




\section{Uji Hipotesis}

Hipotesis penelitian ini akan diuji dengan pengujian statistik uji t dan statistik uji $\mathrm{F}$.

\section{Uji Statistik t}

Digunakan untuk menguji tingkat signifikansi secara parsial atau individu pengaruh variabel citra perusahaan $\left(X_{1}\right)$ terhadap kepuasan pelanggan $(Y)$ dan pengaruh variabel citra perusahaan $\left(X_{2}\right)$ terhadap kepuasan pelanggan $(Y)$. Dengan kriteria pengujian:

$\mathrm{Ha}_{1}$ : Citra perusahaan dan kebijakan promosi berpengaruh signifikan terhadap kepuasan pelanggan pada produk sepeda motor Honda merek Scoopy.

$\mathrm{Ho}_{1}$ : Citra perusahaan dan kebijakan promosi tidak berpengaruh signifikan terhadap kepuasan pelanggan pada produk sepeda motor Honda merek Scoopy.

$\mathrm{Ha}_{2}$ : Citra perusahaan dan kebijakan promosi berpengaruh signifikan terhadap kepuasan pelanggan pada produk sepeda motor Honda merek Scoopy.

$\mathrm{Ho}_{2}$ : Citra perusahaan dan kebijakan promosi tidak berpengaruh signifikan terhadap kepuasan pelanggan pada produk sepeda motor Honda merek Scoopy.

Kriteria pengambilan keputusan untuk uji $\mathrm{t}$ (uji parsial) ada t hitung $\leq \mathrm{t}$ tabel atau $\mathrm{t}$ thitung $\geq-\mathrm{t}$ tabel pada $a=5 \%$ jadi Ho diterima dan $t$ hitung $>$ tabel atau $-t$ hitung $<-t$ tabel pada $a=5 \%$ jadi Ho ditolak (Priyatno, 2012).

\section{Uji Statistik F}

Uji $\mathrm{F}$ digunakan untuk menguji pengaruh variabel independen secara bersama-sama terhadap variabel independen. Pembuktian dilakukan dengan cara membandingkan $F$ Tabel dengan nilai $F_{\text {hitung. }}$. Jika $F$ Hitung lebih besar daripada $\mathrm{F}$ Tabel. Maka keputusannya menolak hipotesis nol $(\mathrm{Ho})$ dan menerima hipotesis alternatif $(\mathrm{Ha})$ (Priyatno, 2012). Model analisis yang digunakan dalam uji $\mathrm{F}$ ini adalah:

$\mathrm{Ha}_{3}$ : Citra perusahaan dan kebijakan promosi berpengaruh signifikan terhadap kepuasan pelanggan pada produk sepeda motor Honda merek Scoopy.

$\mathrm{Ho}_{3}$ : Citra perusahaan dan kebijakan promosi tidak berpengaruh signifikan terhadap kepuasan pelanggan pada produk sepeda motor Honda merek Scoopy

Kriteria pengambilan keputusan Uji $F$ adalah $F_{\text {hitung }} \leq F_{\text {tabel }}$ pada $\alpha=5 \%$ jadi Ho diterima dan $F_{\text {hitung }}>F_{\text {tabel }}$ pada $a=$ 5\% jadi Ho ditolak (Priyatno, 2012).

\section{HASIL PENELITIAN DAN PEMBAHASAN}

\section{Hasil Analisis Regresi}

Pengaruh variabel bebas dan terikat dalam model analisis ini dapat dibuktikan melalui formula regresi berganda (multiple regression). Formulasi ini bertujuan untuk memprediksi sejauh mana tingkat kenaikan skala likert dari 2 (dua) variabel bebas terhadap kenaikan skala variabel terikat pada tingkat kesalahan tertentu (signifikan) atau dimana pengaruh antar variabel tersebut benar-benar nyata (signifikan). Hasil output SPSS regresi linier berganda pengaruh variabel bebas dan terikat dapat dilihat pada Tabel 2.

Tabel 2. Analisis Model Regresi Pengaruh Citra Perusahaan dan Kebijakan Promosi Terhadap Kepuasan Pelanggan Pada Produk Sepeda Motor Honda Merek Scoopy di Kota Banda Aceh

\begin{tabular}{|c|c|c|c|c|c|c|}
\hline \multicolumn{7}{|c|}{ Coefficients $^{\mathrm{a}}$} \\
\hline \multirow{3}{*}{\multicolumn{2}{|c|}{ Model }} & \multirow{2}{*}{\multicolumn{2}{|c|}{$\begin{array}{c}\text { Unstandardized } \\
\text { Coefficients }\end{array}$}} & \multirow{3}{*}{\begin{tabular}{|c|}
$\begin{array}{c}\text { Standardized } \\
\text { Coefficients }\end{array}$ \\
Beta \\
\end{tabular}} & \multirow[b]{3}{*}{$t$} & \multirow{4}{*}{$\begin{array}{l}\text { Sig. } \\
0,01\end{array}$} \\
\hline & & & & & & \\
\hline & & B & Std. Error & & & \\
\hline \multirow[t]{3}{*}{1} & (Constant) & 4,738 & 1,892 & & 2,504 & \\
\hline & Citra Perusahaan & 0,292 & 0,086 & 0,296 & 3,404 & 0,001 \\
\hline & Kebiiakan Promosi & 0,306 & 0,080 & 0,334 & 3,843 & 0,000 \\
\hline
\end{tabular}

a. DependentVariable: Kepuasan Pelanggan

Sumber: Data Primer (diolah), 2021 
Dari hasil perhitungan analisis statistik dengan bantuan program SPSS seperti terlihat pada Tabel 2 di atas, maka dapat diperoleh persamaan regresi sebagai berikut:

$$
Y=4,738+0,292 X_{1}+0,306 X_{2}+e
$$

Dari persamaan regresi di atas dapat diketahui hasil penelitian sebagai berikut:

a. Nilai konstanta kepuasan pelanggan pada produk sepeda motor Honda merek Scoopy sebesar 4,738, menjelaskan jika citra perusahaan $\left(X_{1}\right)$ dan kebijakan promosi $\left(X_{2}\right)$ tidak mengalami perubahan, maka kepuasan pelanggan $(\mathrm{Y})$ pada produk sepeda motor Honda merek Scoopy di Kota Banda Aceh secara konstan hanya sebesar 4,738 satuan.

b. Nilai koefisien regresi pengaruh variabel citra perusahaan $\left(X_{1}\right)$ adalah sebesar 0,292 , dapat diartikan bahwa setiap bertambahnya citra perusahaan pelanggan sebesar 1 satuan, maka akan dapat meningkatkan kepuasan pelanggan pada produk sepeda motor Honda merek Scoopy di Kota Banda Aceh sebesar 0,292 satuan. Dengan demikian jika citra perusahaan pelanggan dapat ditingkatkan maka kepuasan pelanggan pada produk sepeda motor Honda merek Scoopy semakin meningkat.

c. Nilai koefisien regresi pengaruh variabel kebijakan promosi $\left(X_{2}\right)$ sebesar 0,306 , dapat diartikan bahwa setiap adanya peningkatan kebijakan promosi sebesar 1 satuan, maka akan meningkatkan kepuasan pelanggan pada produk sepeda motor Honda merek Scoopy di Kota Banda Aceh sebesar 0,306 satuan. Dengan demikian jika kebijakan promosi dapat ditingkatkan maka kepuasan pelanggan Pada produk sepeda motor Honda merek Scoopy semakin meningkat.

\section{Koefisien Korelasi dan Diterminan}

Pengaruh linier antara citra perusahaan dan kebijakan promosi dengan kepuasan pelanggan selalu memiliki hubungan yang dapat dibuktikan dengan koefisien korelasi dan koefisien diterminan. Koefisien ini menjelaskan keeratan hubungan keseluruhan variabel bebas secara serentak dengan variabel tak bebas. Nilai korelasi bergerak antara -1 sampai dengan +1 dan semakin mendekati nilai 1 atau sama dengan 1 maka korelasi antara variabel akan semakin kuat atau sebaliknya. Sedangkan koefisien determinasi adalah suatu koefisien yang menjelaskan besarnya pengaruh secara serentak variabel-variabel bebas terhadap variabel terikatnya. Dari hasil analisis data dapat diketahui tingkat hubungan variabel bebas dengan variabel terikat sebagaimana terlihat pada Tabel 3.

Tabel 3. Hasil Analisis Korelasi dan Determinasi.

\begin{tabular}{|c|c|c|c|}
\hline Model & $R$ & $R$ Square & Adjusted R Square \\
\hline 1 & $0,515^{\mathrm{a}}$ & 0,265 & 0.255 \\
\hline
\end{tabular}

Sumber: Data Primer (diolah), 2021

Koefisien korelasi $\mathrm{R}$ sebesar 0,515 menjelaskan terdapat hubungan yang positif dan kuat antara variabel citra perusahaan $\left(\mathrm{X}_{1}\right)$ dan kebijakan promosi $\left(\mathrm{X}_{2}\right)$ dengan kepuasan pelanggan $(\mathrm{Y})$ terhadap organisasi pada Pada produk sepeda motor Honda merek Scoopy Kota Banda Aceh. Dengan demikian jika citra perusahaan dan kebijakan promosi pelanggan dapat ditingkatkan maka pelanggan semakin memiliki kepuasan pelanggan yang baik terhadap instansi. Kemudian nilai korelasi determinasi $\left(R^{2}\right)$ sebesar 0,265 menjelaskan, peran variabel citra perusahaan $\left(\mathrm{X}_{1}\right)$ dan kebijakan promosi $\left(\mathrm{X}_{2}\right)$ dalam mempengaruhi kepuasan pelanggan $(\mathrm{Y})$ Pada produk sepeda motor Honda merek Scoopy Kota Banda Aceh adalah sebesar 0,265 (26,5\%). Sementara selebihnya 0,735 $(73,5 \%)$ dipengaruhi oleh variabel lainnya yang tidak dilibatkan dalam penelitian ini. Dengan demikian peran variabel bebas dalam mendukung perubahan variabel terikat dalam model penelitian ini.

\section{Uji Hipotesis \\ Pengujian Secara Simultan (Uji F)}

Hasil perbandingan mean square regresi dan residual diperoleh nilai $F$ hitung sebesar 22,568. Sedangkan nilai $F$ tabel pada taraf signifikan $5 \%$ dan $n=113$ adalah sebesar 3,087. Dengan demikian $F$ hitung $(19,857$.) diperoleh $>F$ tabel $(3,087)$ dengan tingkat probabilitas 0,000 , sehingga hasil penelitian ini dapat diambil suatu keputusan bahwa hipotesis alternatif $(\mathrm{Ha})$ diterima dan menolak hipotesis nol $(\mathrm{Ho})$, artinya citra perusahaan $\left(\mathrm{X}_{1}\right)$ 
dan kebijakan promosi $\left(\mathrm{X}_{2}\right)$ secara simultan berpengaruh signifikan terhadap kepuasan pelanggan pada produk sepeda motor Honda merek Scoopy Kota Banda Aceh.

\section{Pengujian Secara Parsial (Uji t)}

Pembuktian hipotesis secara parsial dapat dijelaskan sebagai berikut.

a. Pengaruh citra perusahaan $\left(X_{1}\right)$ terhadap kepuasan pelanggan $(Y)$ diperoleh nilai t-hitung sebesar 3,404 , sementara nilai t-tabel pada tingkat kesalahan $5 \%$ adalah sebesar 1,984 . Hasil analisis ini menunjukkan bahwa nilai $t_{\text {-hitung }}(3,404)$ lebih besar dari $t_{\text {tabel }}(1,984)$ pada batasan signifikan 0,001 . Dengan demikian hasil perhitungan tersebut menunjukkan bahwa secara parsial citra perusahaan $\left(X_{1}\right)$ berpengaruh signifikan terhadap kepuasan pelanggan $(Y)$ pada produk sepeda motor Honda merek Scoopy di Kota Banda Aceh. Dengan demikian penelitian ini menerima hipotesis $\mathrm{Ha}_{1}$ dan menolak hipotesis $\mathrm{Ho}_{1}$.

b. Pengaruh kebijakan promosi $\left(\mathrm{X}_{2}\right)$ terhadap kepuasan pelanggan $(\mathrm{Y})$ diperoleh nilai $\mathrm{t}_{\text {-hitung }}$ sebesar 3,843 sementara nilai $t_{\text {tabel }}$ pada tingkat kesalahan $5 \%$ adalah sebesar 1,984 . Hasil analisis ini menunjukkan bahwa nilai $t_{\text {-hitung }}(3,843)$ lebih besar dari $t_{\text {tabel }}(1,984)$ pada batasan signifikan 0,000 . Dengan demikian hasil perhitungan tersebut menunjukkan bahwa secara parsial kebijakan promosi $\left(X_{2}\right)$ berpengaruh signifikan terhadap kepuasan pelanggan $(Y)$ pada produk sepeda motor Honda merek Scoopy di Kota Banda Aceh. Dengan demikian penelitian ini menerima hipotesis $\mathrm{Ha}_{2}$ dan menolak hipotesis $\mathrm{Ho}_{2}$.

\section{KESIMPULAN DAN SARAN}

\section{Kesimpulan}

1 Citra perusahaan berpengaruh terhadap kepuasan pelanggan pada produk sepeda motor Honda merek Scoopy Kota Banda Aceh. Dengan demikian jika citra perusahaan pada produk sepeda motor Honda merek Scoopy dapat ditingkatkan oleh perusahaan maka kepuasan pelanggan terhadap produk ini akan semakin meningkat.

2 Kebijakan promosi berpengaruh terhadap kepuasan pelanggan pada produk sepeda motor Honda merek Scoopy Kota Banda Aceh. Dengan demikian jika kebijakan promosi pada produk sepeda motor Honda merek Scoopy dapat ditingkatkan oleh perusahaan maka kepuasan pelanggan terhadap produk ini juga akan semakin meningkat.

3 Hubungan citra perusahaan dan kebijakan promosi dengan kepuasan pelanggan pada produk sepeda motor Honda merek Scoopy Kota Banda Aceh adalah positif dan relatif kuat. Sehingga jika citra perusahaan dan kebijakan promosi pelanggan pada produk sepeda motor Honda merek Scoopy dapat ditingkatkan oleh perusahaan maka kepuasan pelanggan terhadap produk ini akan semakin meningkat.

\section{Saran}

1. Kebijakan promosi perlu ditingkatkan lagi tidak hanya dengan kegiatan seremonial sehingga mereka dapat selalu aktif mengikuti perkembangan produk pada perusahaan ini dan tidak hanya terlibat dalam program promosi saja namun juga kegiatan lain yang bersifat dapat menarik pelanggan baru juga perlu ditingkatkan.

2. Tingkat citra perusahaan pelanggan perlu ditingkatkan dengan melakukan sosialisasi yang agresif kepada para pelanggan.

3. Kebijakan promosi dan citra perusahaan perlu diperhatikan lagi oleh manajemen perusahaan sehingga kepuasan pelanggan dapat dipertahankan secara berkelanjutan.

\section{REFERENSI}

Alma, Buchari. (2007). Manajemen Pemasaran dan Pemasaran Jasa. CV. Alfabeta: Bandung.

Engel, James F, (2002). Costumer Behavior. Jilid Satu Edisi Keenam. Binarupa Aksara: Jakarta.

Kasmir (2007), Kewirausahaan. PT Raja Grafindo Perkasa: Jakarta.

Kotler, Philip. (2005). Manajemen Pemasaran. Jilid 1 dan 2. Jakarta : PT Indeks. 
Kotler, Philip dan Keller, Kevin Lane. (2007). Manajemen Pemasaran Edisi 12. Indeks: Jakarta.

Maholtra, K Naresh. (2005). Marketing Research: An Applied Orientation. Prentice Hall, Inc: New Jersey.

Priyatno, Duwi. (2012). Cara Kilat Belajar Analisis Data dengan SPSS 20. CV. ANDI OFFSET: Yogyakarta:

Saladin, Djaslim. (2003). Intisari Pemasaran. Penerbit Linda Karya: Bandung

Sekaran. Uma (2005). Metode Riset Bisnis. Penerbit Salemba Empat, Jakarta.

Sugiyono. (2005). Memahami Penelitian Kualitatif. Bandung: CV. Alfabeta

Supranto, J. (2002). Mengukur Tingkat kepuasan Pelanggan atau Konsumen. Rineka Cipta: Jakarta.

Susanto, A.B. (2009). Reputation-Driven Corporate Social Responsibility. Jakarta: Erlangga

Sutojo, Siswanto. (2004). Membangun Citra Perusahaan. PT Darma Mulia Pustaka: Jakarta

Swastha D.H., Basu. (2006). Manajemen Pemasaran. Moderen, Edisi Kedua. Liberty: Yokyakarta.

Swastha, Basu dan Irawan. (2002). Manajemen Pemasaran Modern. Liberty: Yogyakarta.

Zeithaml, Valarie A, and Mary Jo Bitner. (1996). Service Marketing, The Mc Graw-Hill Companies, Inc: Singapora.

Zhang, Y. (2009), A Study of Corporate Reputation's influence on Customer Loyalty Based on PLS-SEM Model. International Business Research, Vol.2, No.3. 